\title{
GRAFTING OF Araucaria angustifolia (BERTOL.) KUNTZE THROUGH THE FOUR SEASONS OF THE YEAR ${ }^{1}$
}

\author{
FLÁVIO ZANETTE², LIEGE DA SILVA OLIVEIRA ${ }^{3}$, LUIZ ANTONIO BIASI ${ }^{4}$
}

\begin{abstract}
Araucaria angustifolia is an endangered conifer species of South America that has been over exploited for timber. To incentivize Araucaria angustifolia planting is essential and may play a key role on the conservation of this species and the ecosystems that depend on it. Hence, techniques that allow the production of seedlings with attributes that may entice farmers to plant $A$. angustifolia trees are very important. Grafting may permit the selection of female trees and the production of precocious plants that will produce high quality seeds. The aim of this study was to determine the best season of the year to graft. Three-year-old seedlings were used as rootstock and orthotropic branches of young plants were used for scion collection. The technique used for the grafting was the bark patch. This procedure was carried out in the beginning of each season in 2007 and 2008, with a total of 160 grafted plants. Grafting carried out in the beginning of autumn had a $50 \%$ success rate. Grafting success was negligible for all remaining seasons. In conclusion, grafting through bark patching is a viable technique for the production of $A$. angustifolia seedlings. Future research should be carried out to produce grafted seedlings in large-scale.
\end{abstract}

Index terms: Parana-pine, vegetative propagation, bark patch.

\section{ENXERTIA DE Araucaria angustifolia (BERTOL.) KUNTZE NAS QUATRO ESTAÇÕES DO ANO}

RESUMO - A Araucaria angustifolia, espécie quase exclusiva do Brasil, está ameaçada de extinção devido à extração predatória de sua madeira. É fundamental incentivar o plantio desta espécie, pois desempenha um papel-chave na conservação do ecossistema. Produzir mudas com características que incentivem o plantio é muito importante. A enxertia das mudas pode propiciar a precocidade reprodutiva com produção antecipada de pinhões de alta qualidade. O pinhão, semente da araucária, tem alto valor nutritivo, é rico em amido e proteína, sendo desta forma uma excelente opção alimentar para a população. A comercialização de pinhões pode ser uma saída para estimular o plantio da espécie. O objetivo deste trabalho foi determinar a melhor época do ano para se fazer a enxertia. Foram utilizadas plantas de dois anos e meio de idade como porta-enxerto e ramos ortotrópicos jovens de plantas adultas para os enxertos. A técnica usada para a enxertia foi a placagem lenhosa. Este procedimento foi realizado no início de cada estação do ano, totalizando 160 enxertos. Os enxertos realizados no início do outono tiveram, em média, 50\% de sobrevivência. Nas demais estações, os resultados foram inferiores. Conclui-se que a enxertia por placagem é tecnicamente viável para a produção de mudas de $A$. angustifólia, e o melhor período para enxertar é no início do outono.

Termos para Indexação: Pinheiro-do-paraná, propagação vegetativa, placagem.

\footnotetext{
'(Trabalho 100-11). Recebido em: 23-03-2011. Aceito para publicação em: 07-10-2011.

${ }^{2}$ Eng. Agr., Dr., Programa de Pós-Graduação em Agronomia. UFPR. Rua dos Funcionários, 1540. Cabral. CEP 80035-050. CuritibaPR, Brasil. E-mail: flazan@ufpr.br

${ }^{3}$ Bióloga, Dra ., Rua Francisco Mota Machado n. 993-02, Capão da Imbuia. CEP: 82800-230. Curitiba-PR, Brasil. E-mail: liegeoliveira@bol.com.br

${ }^{4}$ Eng. Agr., Dr., Departamento de Fitotecnia e Fitossanitarismo, UFPR. Rua dos Funcionários, 1540. Cabral. CEP 80035-050. CuritibaPR, Brasil. E-mail: biasi@ufpr.br
} 
The "Ombrófila Mista" forest or "Araucária" forest is an important depository of the neotropical biodiversity and is considered one of the most endangered biomes of the globe. Very intense logging reduced the area occupied by $A$. angustifolia to 1-2 $\%$ of its original size. Despite logging being currently illegal, levels of forest recovery have proven to be insufficient to prevent the local extinction of natural populations of $A$. angustifolia (KOCH; CORREA, 2002).

The $A$. angustifolia edible seed, a large pine nut known as "pinhão", is highly nutritious. Rich in starches and proteins, it has long being consumed in South-America. The commercial potential of these large pine nuts (pinhões) could provide a viable and profitable alternative to logging (GAMA, 2006; ZANETTE, 2010).

A. angustifolia natural propagation occurs through seeds, but seed production starts only when plants are 12 to 15 years old. Seed production could be advanced by grafting techniques used in orchards. Grafted plants are expected to start producing seeds in less than 10 years. Grafting experiments have shown that male and female cones can be produced after four to five years in A. cunninghamii (NIKLES, 1961), and after two to five years in Pinus pinea (CARNEIRO, 2007). In addition to early seed production, grafting would allow orchards with a more balanced sex ratio since plants could be sexed before seed production (ZANETTE, 2010).

Very few studies have been publishing on $A$. angustifolia grafting (GURGEL; GURGEL-FILHO, 1967; KAGEYAMA; FERREIRA, 1975; IRITANI, 1997; ANSELMINI; ZANETTE, 2008), and techniques for the production of grafted seedlings remain to be defined.

Branches of $A$. angustifolia are dimorphic, according to their growth patterns they can be classified as orthotropic or plagiotropic. Orthotropic branches grow at the apex of the tree or at bifurcations of the trunk, which are not very frequent and often have a very large diameter not compatible with potential rootstocks (NIKLES, 1961; GURGEL; GURGELFILHO, 1967; KAGEYAMA; FERREIRA, 1975; HERTEL, 1980). Plagiotropic branches grow horizontally and have a limited life span (IRITANI et al., 1992). When used either for grafting (as scion) or cutting they form abnormal individuals with plagiotropic growth (GURGEL; GURGEL-FILHO, 1967; KAGEYAMA; FERREIRA, 1975; GURGELFILHO, 1980; IRITANI, 1981; IRITANI et al., 1992). Techniques that allow the production of precocious $A$. angustifolia plants that can produce seeds earlier are of fundamental importance. By allowing an earlier production of pine nuts they may add extra value to A. angustifolia trees and hence encourage farmers to plant them. The main objective of this research was to define a grafting protocol for $A$. angustifolia and to identify the best time of the year for its implementation.

The study was conducted from 2006 to 2009 in the experimental unit of the "Departamento de Fitotecnia e Fitossanitarismo - Setor de Ciências Agrárias - Universidade Federal do Paraná", Curitiba - PR, Brazil. In 2006, 18 months old rootstocks, obtained from seeds, were transplanted from the greenhouse to the external environment in plastic pots with 16 litres of soil (Figure 1A). Grafting was performed in 2007 and 2008, during the second week of each season.

Preliminary trials have indicated the use of bark patches as scions was the most efficient grafting technique for $A$. angustifolia.

Bark patches were removed from young lateral branches, with orthotropic growth, collected from eight adult trees (four females and four males - Figures $1 \mathrm{~B}$ and $1 \mathrm{C}$ ). Leaves were removed from the grafting area using fine tip scissors (Figure 1D). Patches were 25 - $35 \mathrm{~mm}$ long, $8 \mathrm{~mm}$ wide and 2 - 3 $\mathrm{mm}$ thick (Figures 1E, 1F and $1 \mathrm{G}$ ).

Bark patches were immediately placed into the bark space of the same size created in the rootstock, just before the last whorl. Once in place, each patch was secured with a fine wire and tape of plastic (Figures $1 \mathrm{H}$ and 1I).

Plastic tapes were removed after 80 days to evaluate the success of the grafting, i.e. to check if the bark patches were alive (Figures $1 \mathrm{~J}$ and $1 \mathrm{~K}$ ). If patches were alive (green) they remained secured with wires for three extra weeks. After 120 days, for all bark patches that remained alive, the rootstock was pruned immediately above the patch. Buddings in the rootstock were always removed.

Each season of the year was considered one experimental treatment. Each treatment was replicated two times (2007 and 2008). Twenty randomly selected plants were allocated to each experimental unit $(\mathrm{N}$ total $=160$ grafted plants $)$. A Chi-squared test with $99 \%$ confidence was used to compare different treatments.

Grafting success, measured as the survival and growth of grafted plants, was significantly higher during autumn $(65 \%$ and $35 \%$, for 2007 and 2008 respectively; Figures 1J, 1L and 1M; Tables 1 and 2 ). It has been previously suggested that autumn is also the best season for grafting of $A$. cunninghamii (NIKLES, 1961).

The beginning of autumn is the most appro- 
priate season to conduct grafting in many fruit trees, when plants have accumulated enough nutrients to allow the formation of new tissues, fundamental in the consolidation of the scion (FAUSTA, 1997).

Assunção (2008) describing the annual growth cycle of $A$. angustifolia, shows that a deceleration of the apparent plastochrom occurs during autumn. Such growth reduction corresponds to a decrease in energy consumption and a potential increase in energy reserve (HARTMANN et al., 2002; TAIZ; ZEIGER, 2004). Future detailed physiological studies would be necessary to clarify which mechanisms are responsible for our results.

Survival rates were extremely low during summer and spring $(0-20 \%$, respectively; Table 1 and 2). According to Assunção (2008), that is the period of more intense vegetative growth in A. angustifolia.

In many fruit trees accelerated growth is a fundamental factor for grafting success (FAUSTA, 1997). During summer and spring, large quantities of resin are produced by $A$. angustifolia. Resin could interfere in the scaring process and hence prevent the consolidation of the scion the success of grafting (Figure 1K).

Only $5 \%$ of the plants grafted during winter survived (Table 1 and 2). A similar pattern was observed for A. cunninghamii (NIKLES, 1961). During winter, resin production decreases and reserves are high, but short photoperiods and low temperatures may limit cellular division and hinder tissue recovery and consequently grafting success. This hypothesis is supported by the fact that surviving plants grafted during winter and spring took more than six months to start budding while plants grafted during autumn took only three months.

Budding in the scion started at the pole of meristematic cells at the base of each leaf (IRITANI et al., 1992). Such meristematic poles cannot be morphologically catheterized as buds and have been described in anatomical studies of several species of Arancariaceae: A. biidwillii, A. klinkii, A. columnaris, A. palmerstonii and A.cunninghamii (NIKLES, 1961).

Cells at the meristematic poles, also known as dormant endogenous buds, are the only meristems capable of producing orthotropic branches when apical dominance is broken (HERTEL, 1980; IRITANI et al., 1992). Hence, collecting scions from orthotropic branches is very important when grafting A. angustifolia.

After the union of scion and rootstock tissues, budding was observed in $96 \%$ of the plants. Kageyama and Ferreira (1975), after testing several grafting techniques have recorded budding rates of
$100 \%$ in $A$. angustifolia plants that survived the grafting.

As expected, the removal of all buddings in the rootstock, more vigorous than the ones in the scion, was fundamental for a healthy development and growth of the scion (CARNEIRO, 2007). The removal of buddings had to be repeated several times to control for persistent buds

During the three years after grafting, plants presented excellent vegetative growth and formation of scar tissue. Some plants $(\mathrm{n}=10)$ transplanted to natural field conditions have achieved $2 \mathrm{~m}$ of height. An essential factor for our successful grafting was the technique of bark patch collection from orthotropic branches. This method circumvents the problem of size incompatibility (diameter) between the rootstock and orthotropic branches since the bark patches used are compatible in size with young rootstocks. Orthotropic buds of decapitated plants and apical buddings of adult plants are always too large to be used in grafting (GURGEL; GURGELFILHO, 1967; KAGEYAMA; FERREIRA, 1975; WENDLING et al., 2009). In addition, orthotropic branches will form plants that grow vertically, hence avoiding the problem of grafted plants with plagiotropic growth obtained with scions extracted from lateral branches of small diameters.

Grafting of Araucaria angustifolia extracting bark patches from orthotropic branches is a viable technique and can be used for plant production.

The beginning of autumn is the best time to graft $A$. angustifolia plants. 

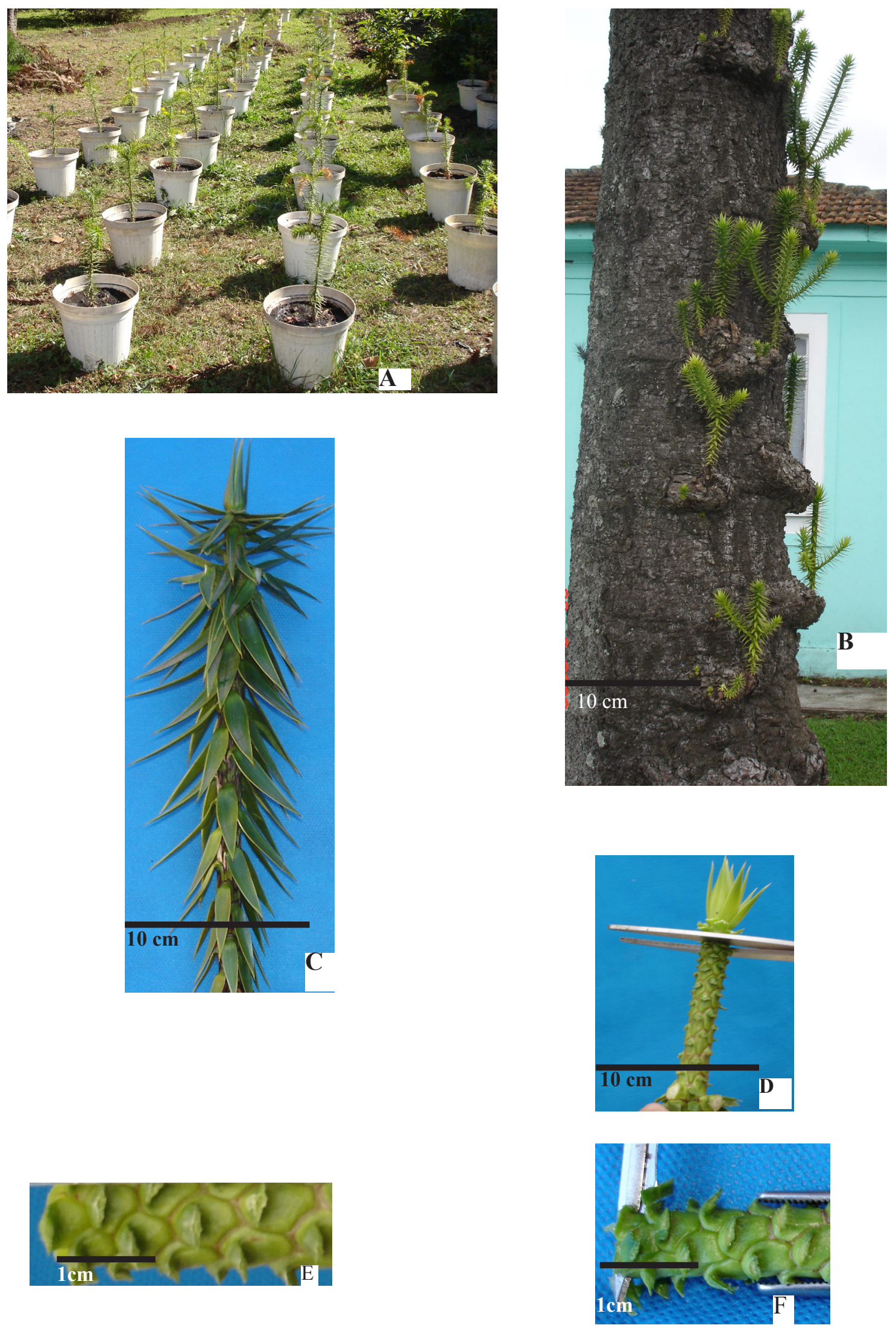

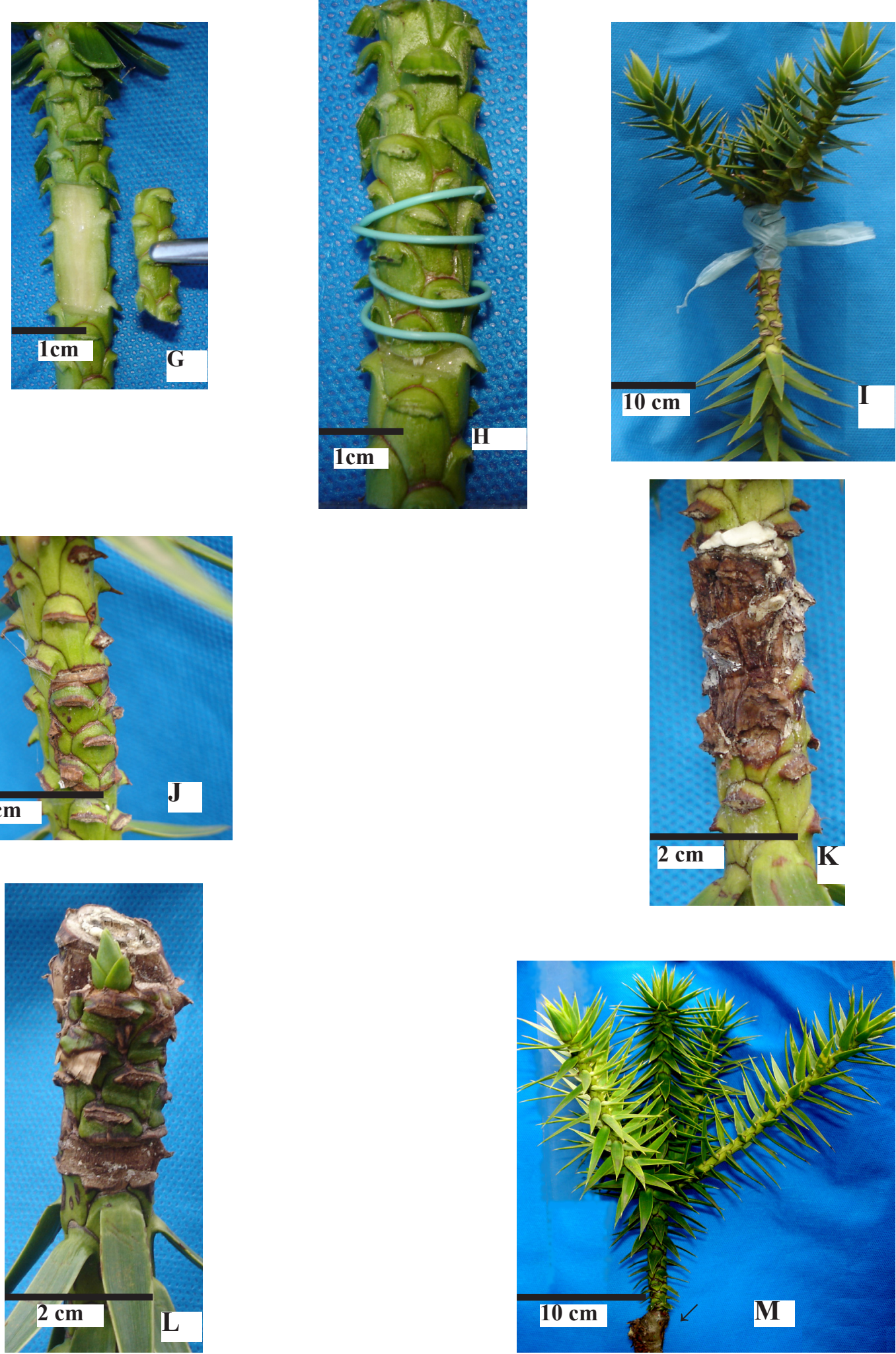

FIGURE 1 - Araucaria angustifolia; A- Three years old rootstock, B, C- Orthotropic branches from adult plants used for grafting; D- Leaf removal; E, F - Bark patch collection; G,H, I - Placement and securing of patch on rootstock; J- Successful autumn grafting after three months ; K- Successful spring grafting; L, M - Successful autumn grafting after eight months and two years, respectively (arrow indicates where the scion placed). 
TABLE 1- Survival rates of Araucaria angustifolia plants grafted in 2007.

\begin{tabular}{lccccc}
\hline \multirow{2}{*}{ Time after grafting } & \multicolumn{5}{c}{ Season } \\
\cline { 2 - 5 } & Autumn & Winter & Spring & Summer & $X^{2}$ \\
\hline 80 days & 65 & 0 & 0 & 0 & $46,56^{* * *}$ \\
120 days & 65 & 0 & 0 & 0 & $46,56^{* * *}$ \\
\hline
\end{tabular}

$* * *$ significant at $\alpha=0.001$

TABLE 2- Survival rates of Araucaria angustifolia plants grafted in 2008.

\begin{tabular}{lccccc}
\hline \multirow{2}{*}{ Time after grafting } & \multicolumn{5}{c}{ Season } \\
\cline { 2 - 5 } & Autumn & Winter & Spring & Summer & \\
\hline 80 days & 40 & 5 & 20 & 0 & $14,23^{* *}$ \\
120 days & 35 & 5 & 20 & 0 & $11,76^{* *}$ \\
\hline
\end{tabular}

** significant at $\alpha=0.01$

\section{REFERENCES}

ANSELMINI, J. I.; ZANETTE, F. Microenxertia e sua caracterização morfológica em Araucaria angustifolia. Ciência Rural, Santa Maria, v.38, n.4, p.967-973, 2008.

ASSUNÇÃO, A. Plastocromo e filocromo aparente anual em Araucaria angustifolia Bert.) O. Ktze, no município de Colombo - PR. 2008. 54f. Dissertação (Mestrado em Agronomia) - Universidade Federal do Paraná, 2008.

CARNEIRO, A. N. Manual ilustrado: enxertia em pinheiro-manso. Lisboa: Instituto Nacional de Investigação Agrária e Pesca, 2007. 41p.

FAUSTA, M. F. Los injertos. Barcelona: Editorial de Vecchi, 1997. 126p.

GAMA, T. M. T. B. Estudo comparativo dos aspectos físico-químicos do pinhão nativo e do pinhão proveniente de processos de polinização controlada de Araucaria angustifolia e da influência do tratamento térmico. 2006. 89f. Dissertação (Mestrado em Tecnologia de Alimentos) - Universidade Federal do Paraná, Curitiba, 2006.

GURGEL, J. T. A.; GURGEL-FILHO, C. A. Métodos de enxertia para o pinheiro brasileiro Araucaria angustifolia (Bertol.) O. Ktze., visando à formação de pomares de sementes. Sivilcultura em São Paulo, São Paulo, v.6, p.153-155, 1967.
GURGEL-FILHO, C. A. Silvicultura da Araucaria angustifolia (Bertol.) O. Ktze. In: ENCONTRO IUFRO PROBLEMAS FLORESTAIS DO GÊNERO ARAUCÁRIA, 1980. Curitiba: IUFRO, 1980. p.29-69.

HARTMANN, H. T.; KESTER, D. E.; DAVIES, J. F.; GENEVE, R. L. Plant propagation: principles and practices. $6^{\text {th }}$ ed. Englewood Cliffs: PrenticeHall, 2002. 647p.

HERTEL, R. J. G. Interpretação morfológica da Araucaria angustifolia. 1980. 143f. Tese (Concurso para professor titular na área de Morfologia Vegetal) - Universidade Federal do Paraná, Curitiba, 1980.

IRITANI, C. Ação de reguladores de crescimento na propagação vegetativa por estaquia de Ilex paraguariensis Saint Hilare e Araucaria angustifolia (Bert.) O. Ktze. 1981. 163f. Dissertação (Mestrado em Engenharia Florestal) - Universidade Federal do Paraná, Curitiba, 1981.

IRITANI, C.; ZANETTE, F.; CISLINSKI, J. Aspectos anatômicos da cultura in vitro da Araucaria angustifolia. I. Organização e desenvolvimento dos meristemas axilares ortotrópicos de segmentos caulinares. Acta Biologica Paranaense, Curitiba, v.21, n.1, 2, 3, 4, p.57-76, 1992.

IRITANI, C. Aspectos múltiplos da cultura in vitro da Araucaria angustifolia (Bert.) O. Ktze. 1997. 200f. Tese (Doutorado em Engenharia Florestal) - Universidade Federal do Paraná, Curitiba, 1997. 
KAGEYAMA, P. Y.; FERREIRA, M. Propagação vegetativa por enxertia Araucaria angustifolia (Bert.) O. Ktze. Instituto de Pesquisas e Estudos Florestais, Piracicaba, n.11, p.95-102, 1975.

KOCH, Z.; CORRÊA M. C. Araucária: a floresta do Brasil Meridional. Curitiba: Olhar Brasileiro, 2002. 148p.

NIKLES, D. G. The development of a new method for grafting hoop on kauri pines. Queensland Forest Service, Brisbane, p.1-31, 1961.
TAIZ, L.; ZEIGER E. Fisiologia vegetal. 3.ed., Porto Alegre: Editora Artmed, 2004. 719p.

WENDLING, I.; DUTRA, L. F.; HOFFMANN, H. A.; BETTIO, G.; HANSEL, F. Indução de brotações epicórmicas para a propagação vegetativa de árvores de $A$. angustifolia. Agronomia Costarricense, San José, v.33, n.2, p.309-319, 2009.

ZANETTE, F. A araucária como fruteira para a produção de pinhões. Jaboticabal: FUNEP, 2010. 25p. (Série Frutas Nativas). 